\title{
PECULIARITIES OF IMMUNORE RESISTANCE CHANGES IN THE EXPERIMENT OF INDUCED PERITONITIS IN ANIMALS OF DIFFERENT AGES
}

\author{
Ivanenko M. O., Klimova O. M., Sherstiuk S. A., Nakonechna S. A.
}

Introduction. The protection of the body against external and internal antigenic factors is executed with the help of the primary cellular and secondary resistance links. Excessive activation of adaptation reactions leads to the formation of various pathologies of inflammatory nature. Changes in the immune responses occur at all ontogenesis stages. In the present study, we conduct the experiment of induced peritonitis in animals of different ages in order to investigate more accurately adaptive responses of the immune system during inflammation.

Objectives. The aim of our research was to study changes in the indicators of adaptive humoral immunity, levels of immunoglobulin A and circulating immune complexes, phagocytic activity of neutrophils and the disruption of enzymes activity, which provide the phagocyte function in the NST test on the model of induced peritonitis in animals of different ages.

Materials and methods. The studies were performed on 200 white male rats. They were divided into a control group and the experimental rats, 3- and 22-month-old ones. Acute inflammation and dysbiosis in the small intestine were caused by intraperitoneal injection of lipopolysaccharide obtained from Escherichia coli strain. The material for the study was serum and blood elements of experimental animals.

Results. The levels of immunoglobulin A in the blood serum of 3 and 22-month-old rats with the inflammation model were reduced in comparison with this index in control group animals. The content of the CIC in the rats blood serum of both age groups was significantly higher in comparison with the control group. All the studied indices of neutrophils phagocytic activity in the 22-month-old animals with the inflammation model were lower than in the control rats of this age. In the 3-month-old rats with the inflammation model, the index of phagocytosis completeness was significantly lower in comparison with the control group. The reduction in the reserve capacity of phagocytic cells was higher in the 22 month-old animals. An increase in the neutrophils metabolic activity and a decrease in their metabolic reserve in 3 and 22month-old rats with the inflammation model were revealed in comparison with the parameters of the control groups.

Conclusions. The results of the study indicate presence of violation of the primary cellular and secondary humoral immunity during the aging of the body and decrease in the adaptive responses of the immune system during inflammation due to an increase in antigenic effects.

KEY WORDS: blood serum, immunoglobulin A, circulating immune complexes, phagocytosis, resistance factors

\section{INFORMATION ABOUT AUTHORS}

Ivanenko Marina O., PhD in Biology, s.r.f. Laboratory of Radiation Immunology, SI «Grigoriev Institute for Medical Radiology of National Academy of Medical Sciences of Ukraine», Pushkinskaya str., 82, Kharkiv, 61024, Ukraine, e-mail: marinaivanenko0204@ gmail.com, https://orcid.org/ 0000-0002-0466-6008

Klimova Olena M., Doctor of Biology, full professor, Head of diagnostic laboratory with immunoassay and immunofluorescence analysis, V. T. Zaytsev Institute of General and Urgent Surgery of National Academy of Medical Sciences of Ukraine, entrance Balakirev, 1, Kharkiv, 61103, Ukraine, e-mail: ionh.info@gmail.com

Sherstiuk Serhii O., Doctor of Medicine, full professor, Head of the Department of Human Anatomy, V. N. Karazin Kharkiv National University, 6, Svobody Sq., Kharkiv, 61022, Ukraine, e-mail: anatomy@karazin.ua, https://orcid.org/0000-0001-6062-7962

Nakonechna Svitlana A., PhD in Biology, associate professor of the Department of Human Anatomy, V. N. Karazin Kharkiv National University, 6 Svobody Sq., Kharkiv, 61022, Ukraine, e-mail: svetmedic2015@ gmail.com

\section{INTRODUCTION}

The protection of the body against external and internal antigenic factors is executed with the help of the primary cellular and secondary resistance links. In the process of recognition and elimination of antigens in the body, various links are gradually included, simultaneously provide all types of immunological defence: phagocytosis, functioning of complement system proteins, killer function of T-lymphocytes, opsonizing effect of immunoglobulin antibodies, cytokine activity [1]. This leads to a reorganization of the relevant metabolic factors 
and provides for adaptation of the body to the environment [2-4]. However, excessive activation of adaptation reactions leads to the formation of various pathologies of inflamematory nature [5-7].

In studying the processes of formation and development of inflammatory reactions, it has been shown that the provision of protection against antigens is carried out with the barrier function of immunocompetent cells and their ability to phagocytosis. Violation of phagocytosis can contribute to the development of dysbacteriosis and various types of diseases, including gastrointestinal tract diseases [8-10]. Changes in the primary and secondary immune responses occur at all ontogenesis stages and leads to the development of inflammatory reactions. From the point of view of adaptogenesis, pathological states can be considered as special reactions of the resistance system in response to the complex of factors simultaneously or sequentially affecting the organism. It is natural that a large number of experimental and theoretical works are devoted to studying the formation of various resistance mechanisms [11-12]. Regardless of the research level (molecular, physiological or population), the same methodological approach is used - the evaluation of the biological system reaction in response to a particular impact. Most of these studies are aimed at determining the general patterns and mechanisms for the response formation. The development of adaptogenesis concepts is impossible without proper consideration of induction ontogenetic features of primary and secondary adaptive factors of resistance.

\section{OBJECTIVE}

The aim of the work was to evaluate the interaction features of primary cellular and secondary humoral immunophysiological factors of resistance in the induced inflammatory process on the experimental model. To achieve this goal, the following tasks were set:

1. To detect changes in the parameters of adaptive humoral immunity, levels of immunoglobulin A and circulating immune complexes in the experiment of induced peritonitis in animals of different ages.

2. To evaluate the peculiarities of changes in the activity of phagocytosis and enzymes of phagocytic cells of granulocyte neutrophils in experimental animals on the model of inflammation.

\section{MATERIALS AND METHODS OF RESEARCH}

The studies were performed on white 3-month-old male rats weighing 100-140 $\mathrm{g}$ and 22 -month-old ones weighing 200-240 g. In total, 200 animals were used in the work. Acute inflammation and dysbiosis in the small intestine were caused by intraperitoneal injection of lipopolysaccharide (LPS) obtained from Escherichia coli strain 0111: B4 (Sigma, USA) at the rate of $100 \mu \mathrm{g} / \mathrm{kg}$ of body weight in $1 \mathrm{ml}$ of isotonic $\mathrm{NaCl}$ solution. The control group consisted of the same age animals as the experimental rats. The animals were kept under standard light and food regimes (water and food ab libitum) .The material for the study was serum and blood elements of experimental animals .The studies were conducted in accordance with the «General ethical principles of conducting experiments on animals»and the norms of the «European Convention on the Protection of Vertebrate Animals used for experiments and other scientific purposes» [1315].

To determine the state of the humoral component of immune system, the concentration of circulating immune complexes (CIC) in the blood serum was determined by spectrophotometric method and the concentration of immunoglobulin A - by turbidimetric method [16, 17]. Neutrophil granulocytes were isolated from peripheral blood. In the study of phagocytic activity of peripheral blood neutrophils, the method of complete phagocytosis was used [18]. The following parameters of phagocytic activity were estimated: the number of phagocytic neutrophils (PNP), phagocytic number (PN), and the index of phagocytosis completeness (IPC).

Oxygen metabolism of neutrophils was judged by their ability to absorb nitrosinetetrazole (NST) and restore it to the diformazanin the form of blue granules under the influence of superoxide anion, formed in the NADPH-oxidase reaction [19]. The experimental data were processed by conventional methods of variational statistics [20]. The statistical processing of the digital data was carried out using the BIOSTAT program (ver 4.03) [21]. 


\section{RESULTS AND DISCUSSION}

The evaluation of $\operatorname{IgA}$ content in the serum of 3 and 22-month-old control animals and animals with the model of inflammation

Age-dependent immunopathological conditions should be realized in all parts of the immunological defence. The violation of the barrier phagocytic functions can lead to the formation disruption of the secondary humoral immune response, which is realized at the level of immunoglobulin synthesis. It is known that there is certain correlation between a high level of $\operatorname{IgA}$ in the serum and the severity of the inflammatory process, while the content decrease of this immunoglobulin in the serum indicates the development of anergy or irreversible immunodeficiency.

The study of $\operatorname{IgA}$ concentration in the serum showed this index decrease in both groups of animals with the model inflammation relative to the reference values. A more pronounced decrease was noted in 3-month-old rats $((0.42 \pm$ $0.05) \mathrm{g} / 1$ vs. $(1.30 \pm 0.09) \mathrm{g} / 1$ in the control group) (fig. 1). A decrease in IgA concentration may indicate some lack of humoral component of immune system, as well as its adsorption on immune complexes [22].

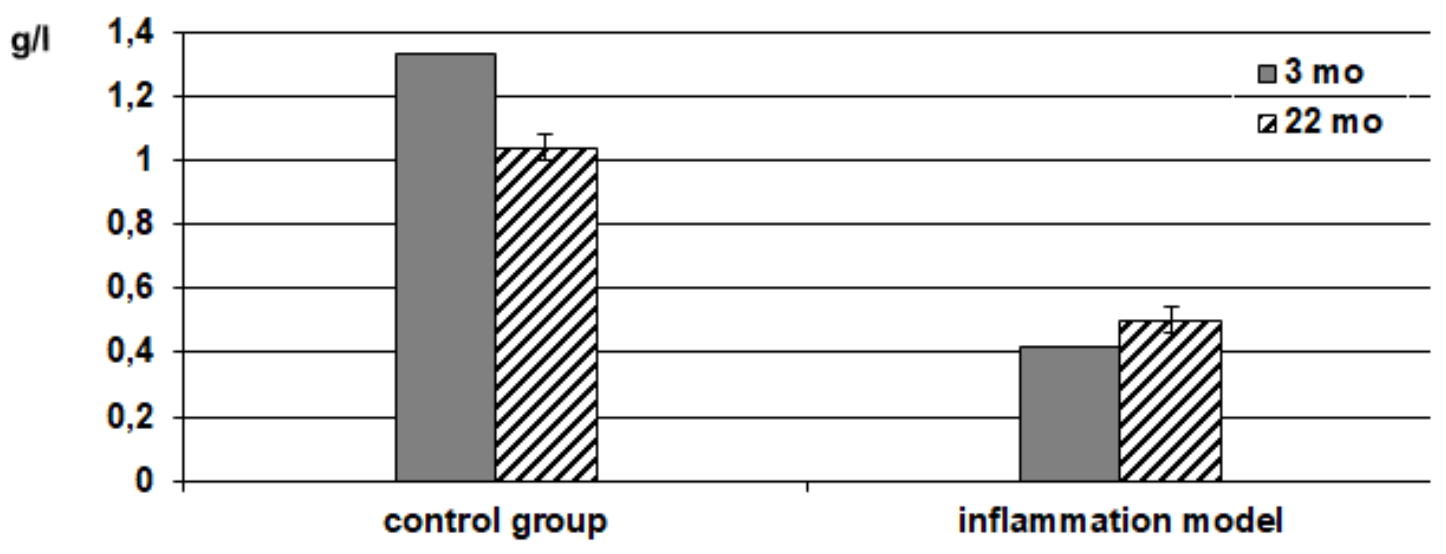

Fig. 1. IgA content in serum 3 and 22-month-old control animals and animals with the inflammation model.

Studying of circulating immune complexes in experimental animals of different ages on the inflammation model

Since one of the biological functions of immunoglobulins is the neutralization of antigens with the formation of circulating immune complexes (CIC), it was expedient to evaluate their content in the serum of animals of different age groups. Under physiological conditions, the formation and presence of the CIC in liquids is one of the manifestations of the body immune response to the ingestion of antigens and is an important factor providing for immunity [23].

In the case of pathological changes in the body, the increased formation of circulating immune complexes and their prolonged circulation in body fluids can lead to their accumulation in tissues, which triggers a chain of cytotoxic changes that cause autoimmune diseases. The serum CIC level is an important indicator of immunological reactivity, since it shows not only the degree of organism loading by antigens of infectious agents, but also destructive degenerative phenomena in the body and can characterize the processes of biosynthesis of antibodies as a whole [24]. The study CIC level in the blood serum of 3 and 22-month-old animals with the model of inflammation revealed a significant increase in these parameters in comparison with the control group. In 22-month-old animals this increase was more significant and corresponded to the value $(224.0 \pm 13.0)$ of relative units, at $(150.0$ \pm 0.5 ) relative units in the control group and in 3 -month-old animals $(208.0 \pm 2.0)$ relative units at $(170.0 \pm 1.0)$ relative units in the control group. It can be assumed that the increase in CIC level is the consequence of the imbalance between their formation and elimination, or is 
associated with the deficiency of one or more components of the compliment.

The study of primary and secondary immunity indices revealed age features of these parameters in control group animals and in the rats with the model of inflammation. The phagocytic index (PI) and phagocytic number (PN) in control rats of different ages did not differ significantly. PI is equal to $(81.17 \pm$ $5 / 40) \%$ and $(82.33 \pm 5.40) \%$, and PN is $3.62 \pm$ 0.20 relative units and $(3.71 \pm 0.20)$ relative units in 3 and 22-month-old rats, respectively.
The index of phagocytosis completeness in 3month-old animals was significantly higher than in 22-month-old rats $(1.44 \pm 0.03)$ relative units vs $(1.13 \pm 0.03)$ relative units (tab. 1$)$. In 3-month-old rats with the inflammation model, PI and PN did not significantly differ from those of the control animals (see tab. 1). The index of phagocytosis completeness in 3-month-old rats with inflammation was significantly lower than the control values and was $(1.25 \pm 0.03)$ relative units.

Functional activity of phagocytic neutrophils in control animals and in animals with the inflammation model

\begin{tabular}{|c|c|c|c|c|c|c|}
\hline \multirow{2}{*}{ Rat age } & \multicolumn{6}{|c|}{ Animals } \\
\cline { 2 - 7 } & Control animals & \multicolumn{4}{|c|}{ With the inflammation model } \\
\cline { 2 - 7 } & PI,\% & $\begin{array}{c}\text { PN, } \\
\text { relative } \\
\text { units. }\end{array}$ & $\begin{array}{c}\text { CI, } \\
\text { relative } \\
\text { units. }\end{array}$ & PI, \% & $\begin{array}{c}\text { PN, } \\
\text { relative } \\
\text { units. }\end{array}$ & $\begin{array}{c}\text { CI, } \\
\text { relative units. }\end{array}$ \\
\hline $\begin{array}{c}3 \\
\text { month. }\end{array}$ & $81,17 \pm 5,40$ & $3,62 \pm 0,20$ & $1,44 \pm 0,03$ & $76,71 \pm 5,40$ & $3,71 \pm 0,20$ & $1,25 \pm 0,03 *$ \\
\hline $\begin{array}{c}22 \\
\text { month. }\end{array}$ & $82,33 \pm 5,40$ & $3,71 \pm 0,20$ & $1,13 \pm 0,03$ & $66,84 \pm 5,40^{*}$ & $2,86 \pm 0,20$ & $0,95 \pm 0,03 * \mathrm{X}$ \\
\hline
\end{tabular}

Notes: Significant differences: 1) * - in comparison with the control, 2) X-between age groups, $P<0.05$.

In 22-month-old animals with the inflammation model, all the investigated indices of neutrophil activity were lower than in the control rats. The data obtained indicate incompleteness of the phagocytosis reactions in 3 and 22-month-old rats with the inflammation model testifying to the dissociation of absorption and digestion processes in these animals. Along with the study of phagocytosis, the ability of neutrophils to form active forms of oxygen was determined with the help of the NST test [19]. To evaluate the bactericidal status, the resource potential, and the ability of neutrophils to complete phagocytosis, a spontaneous and stimulated neutrophil reaction was studied.

When studying neutrophils metabolic activity with the NST test in the control 3-month-old animals, a higher value of the stimulation index of (SI) of rats was found in comparison with this index in the 22-month-old animals (fig. 2). In 3 and 22-month-old experimental animals with the inflammation model, an increase in the metabolic activity of neutrophils was observed.

In the animals of both age groups with the inflammation model, the average cytochemical index (ACI) was spontaneous (sp) and stimulated (st) were higher in comparison with the control group (fig. 3).

The index of SI in animals with the inflammation model was lower than in the control group animals, which may indicate the beginning of the suppressive phase or the depletion of neutrophils functional activity. 

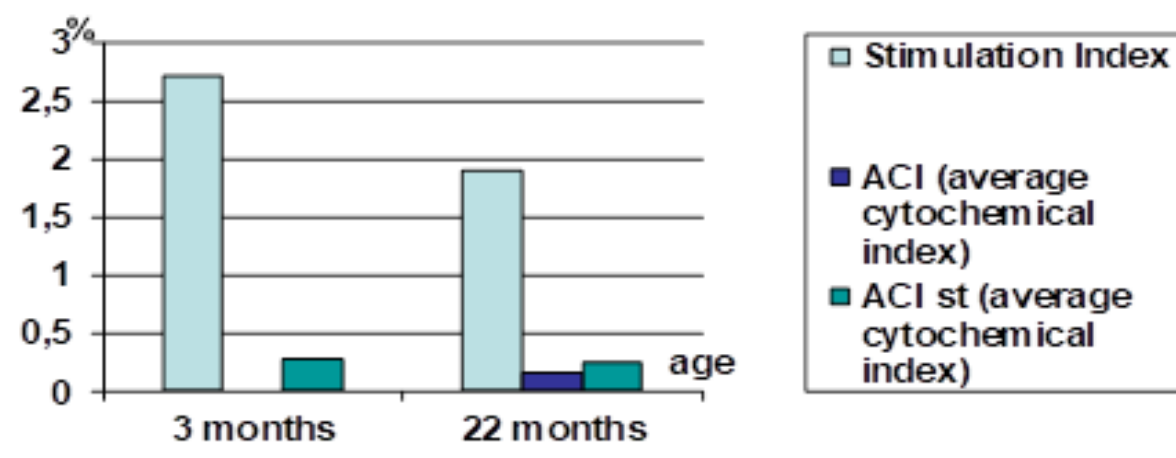

Fig. 2. Indicators of the NST test in control group animals of 3 and 22 months of age

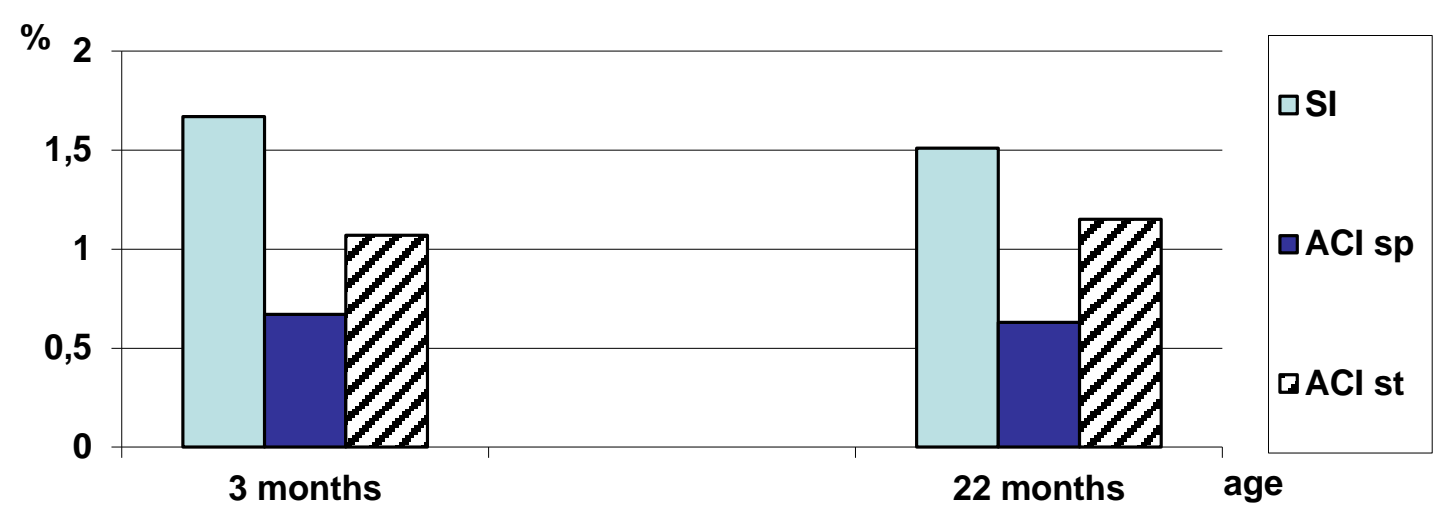

Fig. 3. Indicators of the NST-test in 3 and 22-month-old experimental animals with the inflammation model

\section{CONCLUSIONS}

1. The results of the study indicate certain violation of the primary cellular and secondary humoral immunity during the aging of the body and decrease in the adaptive responses of the immune system during inflammation due to an increase in antigenic effects.

2. The levels of immunoglobulin $\mathrm{A}$ in the blood serum of 3 and 22-month-old rats with the inflammation model were reduced in comparison with this index in control group animals.

3. The content of the CIC in the rats blood serum of both age groups was significantly higher in comparison with the control group.

4. All the studied indices of neutrophils phagocytic activity in the 22-month-old animals with the inflammation model were lower than in the control rats of this age. In the 3-monthold rats with the inflammation model, the index of phagocytosis completeness was significantly lower in comparison with the control group. The reduction in the reserve capacity of phagocytic cells was higher in the 22-monthold animals. An increase in the neutrophils metabolic activity and a decrease in their metabolic reserve in 3 and 22-month-old rats with the inflammation model were revealed in comparison with the parameters of the control groups.

\section{PROSPECTS FOR FUTURE STUDIES}

Further study of changes in humoral immunity in case of induced peritonitis in animals under the influence of various immunomodulators remains promising. Also it is interesting to study the change in the composition of the intestinal microbiota in this occasion, given the existence of a gut-brain axis. 


\title{
REFERENCES
}

1. Abbas, A. K., Lichtman, A. H. H., Pillai, S. (2015). Basic Immunology E-Book: Functions and Disorders of the Immune System. Elsevier Health Sciences.

2. Pavlov, V. A., Terrando, N. (2018). Neuro-immune interactions in inflammation and autoimmunity. Frontiers in immunology. 9. P. 772.

3. Pavlov, V. A., Tracey, K. J. (2017). Neural regulation of immunity: molecular mechanisms and clinical translation. Nature neuroscience. 20 (2). P. 156.

4. Tracey, K. J. (2018) Neurons are the inflammatory problem. Cell. 173 (5). P. 1066-1068.

5. Huang, Y., Chen, Z. (2016). Inflammatory bowel disease related innate immunity and adaptive immunity. American journal of translational research. 8 (6). P. 2490.

6. Hotamisligil, G. S. (2017.) Inflammation, metaflammation and immunometabolic disorders. Nature. 542 (7640). P. 177.

7. Chen, L. et al. (2018). Inflammatory responses and inflammation-associated diseases in organs. Oncotarget. 9 (6). P. 7204.

8. Lamont, R. J., Hajishengallis, G. (2015). Polymicrobial synergy and dysbiosis in inflammatory disease. Trends in molecular medicine. 21 (3). P. 172-183.

9. Winter, S. E. (2016). Mechanisms of Dysbiosis in the Inflamed Gut. Host-Pathogen Interaction: Microbial Metabolism, Pathogenicity and Antiinfectives. P. 77-92.

10. Leonardi, I. et al. (2018). CX3CR1+ mononuclear phagocytes control immunity to intestinal fungi. Science. 359 (6372). P. 232-236.

11. Kenney, M. J., Ganta, C. K. (2014). Autonomic nervous system and immune system interactions. Comprehensive physiology. 4 (3). P. 1177-1200.

12. Scanzano, A., Cosentino, M. (2015). Adrenergic regulation of innate immunity: a review. Frontiers in pharmacology. 6. P. 171.

13. Uranov, V.N. (1995). Medical associations, medical ethics and general medical problems. M .: Publishing House of PIIMS, (in Russian).

14. Kundiev, Yu. I. (2006). The state of bioethics in Ukraine. Medichnij vsesvit. 2(1-2), 41-46, (in Russian)

15. Komarov, F. I., Rapoport, S. I., \& Chibisov, S. M. (2007). The role of the problem commission «Chronobiology and chronomedicine of the Russian Academy of Medical Sciences in the development of internal medicine» (on the 25th anniversary of creation). Klinicheskaja medicina, 85 (9), 14-16, (in Russian).

16. Karpishhenko, A. I. (2002). Medical laboratory technologies and diagnostics: a reference book in 2 volumes. SPb: Intermedika. 408 p, (in Russian).

17. Gamaleja, N. B., Mondrus, K. A. (1994). Comparison of two methods for the determination of immunoglobulin classes A, M, G (spectrophotometry and radial immunodiffusion). Klin. lab. Diagnostika. 1. P. 6-7, (in Russian).

18. Kudrjavickij, A. I. (1985). Evaluation of the killer bactericidal activity of neutrophils from the peripheral blood of healthy donors and patients in a direct visual test. Lab. delo. - №. 1. - P. 45-47, (in Russian)

19. Viksman, M. E., Majanskij, A. N. (1979). A method for evaluating the functional activity of human neutrophils by the reduction reaction of nitro blue tetrazolium, (in Russian).

20. Glanc, S. Et al. (1999). Biomedical statistics. M.: praktika. 459. P. 1, (in Russian).

21. Lapach, S. N., Chubenko, A. V., Babich P. N. (2000). Statistical methods in biomedical research using Excel. Kiev: Morion. 320. P. 2010, (in Russian).

22. Bondarenko, V. M. (2013.) The mechanisms of translocation of bacterial autoflora in the development of endogenous infection // Bjulleten' Orenburgskogo nauchnogo centra URO RAN. 3. P.1-21, (in Russian).

23. Pozur, V. V. et al. (2015) Reaction of lymphotic organisms in the presence of multi-sampling «Simbiter atsidofilny» in schur v with glutamate ozhirinnyam. P. 50-57, (in Ukrainian).

24. Kozak, D. V. (2013). Dynamics of circulating immune complexes and immunoglobulins in response to polytrauma in experiment. Klinichna khirurhiia. 12. P. 76-78.

\section{ОСОБЛИВОСТІ ЗМІНИ ІМУНОРЕЗИСТЕНТНОСТІ В ЕКСПЕРИМЕНТІ ІНДУКОВАНОГО ПЕРИТОНІТУ У ТВАРИН РІЗНОГО ВІКУ}

\author{
Іваненко М. О., Клімова О. М., Шерстюк С. О., Наконечна С. А.
}

Вступ. Захист організму від зовнішніх і внутрішніх антигенних факторів здійснюється за допомогою первинних клітинних і вторинних резистентних ланок. Надмірна активація адаптаційних реакцій призводить до утворення різних патологій запального характеру. Зміни в імунних реакціях відбуваються на всіх етапах 
онтогенезу. У представленому дослідженні ми провели експеримент з індукованим перитонітом у тварин різних вікових груп, щоб більш точно дослідити адаптаційні реакції імунної системи при запаленні.

Мета. Метою нашого дослідження було вивчення змін показників адаптивного гуморального імунітету, рівнів імуноглобуліну А та циркулюючих імунних комплексів (ЦІК), фагоцитарної активності нейтрофілів і порушення активності ферментів, які забезпечують функцію фагоцитів в НСТ-тесті на моделі індукованого перитоніту у тварин різних вікових груп.

Матеріали та методи. Дослідження проводилися на 200 білих щурах-самцях. Вони були розділені на контрольну групу і експериментальних щурів віком 3 і 22 місяців. Гостре запалення і дисбіоз в тонкій кишці були викликані внутрішньочеревною ін'єкцією ліпополісахарида, отриманого зі штаму Escherichia coli. Матеріалом для дослідження були сироватка і елементи крові експериментальних тварин.

Результати. Рівні імуноглобуліну А в сироватці крові щурів 3 і 22 місяців в моделі запалення були знижені в порівнянні $з$ цим показником у тварин контрольної групи. Зміст ЦІК в сироватці крові щурів обох вікових груп був значно вище в порівнянні з контрольною групою. Всі вивчені показники фагоцитарної активності нейтрофілів у 22-місячних тварин з моделлю запалення були нижче, ніж у контрольної групи цього віку. У 3 -місячних щурів 3 моделлю запалення індекс завершеності фагоцитозу був значно нижчий в порівнянні 3 контрольною групою. Зниження резервної ємності фагоцитарних клітин було більш виражене у 22-місячних тварин. Виявлено збільшення метаболічної активності нейтрофілів і зниження їх метаболічного резерву у щурів 3 і 22 місяців 3 моделлю запалення в порівнянні з показниками контрольної групи.

Висновки. Результати дослідження свідчать про наявні порушення первинного клітинного і вторинного гуморального імунітету при старінні організму і зниження адаптаційних реакцій імунної системи при запаленні внаслідок посилення антигенних ефектів.

КЛЮЧОВІ СЛОВА: сироватка крові, імуноглобулін А, циркулюючі імунні комплекси, фагоцитоз, фактори резистентності

\section{ІНФОРМАЦІЯ ПРО АВТОРІВ}

Іваненко Марина Олегівна, к.біол.н., с.н.с. лабораторії радіаційної імунології ДУ «Інститут медичної радіології імені С. П. Григор'єва Національної академії медичних наук України», вул. Пушкінська, 82, Харків, Україна, 61024, e-mail: marinaivanenko0204@gmail.com, https://orcid.org/ 0000-0002-0466-6008.

Клімова Олена Михайлівна, д.біол.н., професор, завідувач діагностичної лабораторії з імуноферментним та імунофлюоресцентним аналізом, ДУ «Інститут загальної та невідкладної хірургії імені В. Т. Зайцева НАМН України», в’їзд Балакірєва, 1, Харків, Україна, 61103, e-mail: ionh.info@gmail.com

Шерстюк Сергій Олексійович, д.мед.н., професор, завідувач кафедри анатомії людини, Харківського національного університету імені В. Н. Каразіна, майдан Свободи, 6, Харків, Україна, 61022 , e-mail: anatomy@karazin.ua, https://orcid.org/0000-0001-6062-7962

Наконечна Світлана Анатоліївна, к.біол.н., доцент кафедри анатомії людини, Харківського національного університету імені В. Н. Каразіна, майдан Свободи, 6, Харків, Україна, 61022, e-mail: svetmedic2015@ gmail.com

\section{ОСОБЕННОСТИ ИЗМЕНЕНИЙ ИММУНОРЕЗИСТЕНТНОСТИ В ЭКСПЕРИМЕНТЕ ИНДУЦИРОВАННОГО ПЕРИТОНИТА У ЖИВОТНЫХ РАЗНОГО ВОЗРАСТА}

\section{Иваненко М. О., Климова Е. М., Шерстюк С. А., Наконечная С. А.}

Вступление. Защита организма от внешних и внутренних антигенных факторов осуществляется с помощью первичных клеточных и вторичных резистентных звеньев. Чрезмерная активация адаптационных реакций приводит к образованию различных патологий воспалительного характера. Изменения в иммунных реакциях происходят на всех этапах онтогенеза. В представленном исследовании мы провели эксперимент с индуцированным перитонитом у животных разных возрастов, чтобы более точно исследовать адаптационные реакции иммунной системы при воспалении.

Цели. Целью нашего исследования было изучение изменений показателей адаптивного гуморального иммунитета, уровней иммуноглобулина А и циркулирующих иммунных комплексов (ЦИК), фагоцитарной активности нейтрофилов и нарушения активности ферментов, которые обеспечивают функцию фагоцитов в НСТтесте на модели индуцированного перитонита у животных разных возрастов.

Материалы и методы. Исследования проводились на 200 белых крысах-самцах. Они были разделены на контрольную группу и экспериментальных крыс возрастом 3 и 22 месяцев. Острое воспаление и дисбиоз в тонкой кишке были вызваны внутрибрюшинной инъекцией липополисахарида, полученного из штамма Escherichia coli. Материалом для исследования послужили сыворотка и элементы крови экспериментальных животных.

Результаты. Уровни иммуноглобулина А в сыворотке крови крыс 3 и 22 месяцев в модели воспаления были снижены по сравнению с этим показателем у животных контрольной группы. Содержание ЦИК в сыворотке крови крыс обеих возрастных групп было значительно выше по сравнению с контрольной группой. Все изученные показатели фагоцитарной активности нейтрофилов у 22-месячных животных с моделью воспаления были ниже, чем у контрольных крыс этого возраста. У 3-месячных крыс с моделью воспаления индекс завершенности фагоцитоза был значительно ниже по сравнению с контрольной группой. Снижение резервной емкости фагоцитарных клеток было значительнее у 22-месячных животных. Выявлено увеличение метаболической активности нейтрофилов и снижение их метаболического резерва у крыс 3 и 22 месяцев с моделью воспаления по сравнению с показателями контрольных групп. 
Выводы. Результаты исследования свидетельствуют о наличии нарушений первичного клеточного и вторичного гуморального иммунитета при старении организма и снижении адаптационных реакций иммунной системы при воспалении из-за усиления антигенных эффектов.

КЛЮЧЕВЫЕ СЛОВА: сыворотка крови, иммуноглобулин А, циркулирующие иммунные комплексы, фагоцитоз, факторы резистентности

\section{ИНФОРМАЦИЯ ОБ АВТОРАХ}

Иваненко Марина Олеговна, к.биол.н., с.н.с. лаборатории радиационной иммунологии ГУ «Институт медицинской радиологии имени С. П. Григорьева Национальной академии медицинских наук Украины», ул. Пушкинская, 82, Харьков, Украина, 61024, e-mail: marinaivanenko0204@gmail.com, https://orcid.org/ 0000-00020466-6008

Климова Елена Михайловна, д.биол.н., профессор, заведующий диагностической лаборатории с иммуноферментным и иммунофлюоресцентным анализом, ГУ «Институт общей и неотложной хирургии имени В. Т. Зайцева НАМН Украины », въезд Балакирева, 1, Харьков, Украина, 61103, e-mail: ionh.info@ gmail.com

Шерстюк Сергей Алексеевич, д.м.н., профессор, заведующий кафедрой анатомии человека, Харьковского национального университета имени В.Н. Каразина, площадь Свободы, 6, Харьков, Украина, 61022, e-mail: anatomy@karazin.ua, : https://orcid.org/0000-0001-6062-7962

Наконечная Светлана Анатольевна, к.биол.н., доцент кафедры анатомии человека, Харьковского национального университета имени В. Н. Каразина, площадь Свободы, 6, Харьков, Украина, 61022, e-mail: svetmedic2015@gmail.com 